\title{
Small ruminant lentivirus infection influences expression of acute phase proteins and cathelicidin genes in milk somatic cells and peripheral blood leukocytes of dairy goats
}

\author{
Daria Reczyńska' ${ }^{1}$ Magdalena Zalewska', Michał Czopowicz², Jarosław Kaba², Lech Zwierzchowski \\ and Emilia Bagnicka ${ }^{1 *}$ (1)
}

\begin{abstract}
The aim of the study was to analyze acute phase protein and cathelicidin gene responses to small ruminant lentivirus (SRLV) infection in goats. In uninfected goats, we found higher $C p$ and lower Fby mRNA levels in blood leucocytes (BL) than in milk somatic cells (MSC), as well as lower SAA, Hp, and CRP and higher Cp and AGP concentrations in blood serum than in milk. In SRLV-infected goats, we found higher Fby and MAP28 and lower Cp expression in MSC than in $\mathrm{BL}$, and higher SAA, Hp, Fb, and MAP28 and lower AGP concentrations in milk than in blood serum. Higher SAA and Hp expressions in BL and Hp expression in MSC were found in SRLV-infected goats. In SRLV-infected goats, we observed a higher concentration of SAA in blood serum, while in milk, lower SAA, Cp, and MAP28 and higher MAP34 concentrations were observed. The expression profiles of the studied genes differed between BL/serum and MSC/milk. The elevated SAA concentration in blood serum was accompanied by a decreased concentration of SAA and Cp in the milk of infected goats. No differences in the expression of the other studied genes may mean that the SRLV has the ability to evade the immune system, continuing to replicate. The elevated concentration of SAA in blood serum may promote viral multiplication. This higher concentration of SAA in blood serum and simultaneous reduced concentration of SAA and CP in milk may be additive indicators of this infection.
\end{abstract}

\section{Introduction}

Small ruminant lentivirus (SRLV) causes chronic diseases in domestic and wild small ruminants. Caprine arthritisencephalitis virus (CAEV) and visna-maedi virus (VMV), responsible for diseases in goats and sheep, respectively, were first considered to be two related but separate pathogens. However, through phylogenetic and epidemiologic analysis, they were then merged into a single species, that of SRLV. SRLV belongs to the Lentivirus genus, Retroviridae family together with human (HIV), simian (SIV), and feline immunodeficiency (FIV) viruses. Lentiviruses are

\footnotetext{
*Correspondence: e.bagnicka@ighz.pl

${ }^{1}$ Department of Animal Improvement, Institute of Genetics and Animal Breeding, Polish Academy of Sciences, Postępu 38A St. 05-552 Jastrzębiec, Poland

Full list of author information is available at the end of the article
}

characterized by high biodiversity - a direct consequence of their retroreplication mechanism, which results in a high number of point mutations [1]. This phenomenon suggests the possible emergence of new recombinant variants of the virus genome, which can acquire a new host (analogous to the history of SIV-HIV/AIDS) [2]. Therefore, there is a need to study all aspects of the disease, including the host's immunological response, at the molecular level.

The main target cells for SRLV are monocytes, macrophages, and dendritic cells but not lymphocytes. SRLV cause a systemic infection that may also affect the central nervous system, in addition to the mammary gland, and respiratory and musculoskeletal system [3]. The maturation of blood monocytes into tissue macrophages initiates virus replication within these cells [4]. The disease 
eventually leads to emaciation and the premature culling of animals, but at different times after infection [5]. Goats with clinical symptoms of the disease suffer from arthritis, which causes severe pain. The infection is difficult to diagnose, as only $30 \%$ of the infected animals develop apparent signs [6]. Moreover, the blood antibody titer can remain below the limit of detection, even long after the infection. Thus serological ELISA (enzymelinked immunosorbent assay), cannot be considered as a reference test $[7,8]$, which necessitates search for additional biomarkers of the infection. We hypothesize that the concentration or the mRNA level of some proteins involved in the immune defense against viruses could play this role.

Because human safety and animal welfare are priorities in developed societies, the eradication of SRLV has become an urgent need $[2,6]$. There is currently no effective therapy against caprine arthritis-encephalitis (CAE), so the most effective way to eradicate this disease is to wean kids from infected dams immediately after birth, rearing them on bovine colostrum/milk or milk replacement, and remove infected animals from the herd [6]. Moreover, reducing the virus load in the infected animals could improve the welfare of animals and prolong their life $[9,10]$. It is important to understand the complexity of pathogenesis and the precise mechanisms responsible for SRLV infection.

The molecular basis of an organism's immune response to pathogen invasion in domestic animals has recently become one of the most intensively studied topics in the field of veterinary medicine. In this study, we focus mainly on acute phase proteins (APP) and cathelicidins. APP are various glycoproteins with diverse structures, functions, and expression levels. In general, they can be divided into two subgroups: positive APP, whose concentration increases, and negative APP, whose concentration decreases in response to the stimulus [11]. Usually, their concentrations in blood change within 24-48 h after infection, but they can also serve as an indicator of chronic inflammation [12]. In domestic animals, the positive group includes: serum amyloid A (SAA), haptoglobin (Hp), C-reactive protein (CRP), ceruloplasmin $(\mathrm{Cp})$, fibrinogen $(\mathrm{Fb}), \alpha_{1}$-acid glycoprotein (AGP), and lactoferrin (Lf). The negative group includes albumins, transferrin (Tf), and transthyretin (TTR) [13]. Thus far, only five proteins have been identified in goats as positive APP-SAA, Hp, Cp, Fb, AGP and one negativealpha-lactalbumin (LALBA). Their expression has been detected in a broad range of cells, such as hepatocytes, and leukocytes or epithelial cells of various organs [14].

Cathelicidins are an another important component of the innate immune system. They are small cationic peptides belonging to a wide, heterogeneous group of cationic antimicrobial peptides (AMP). They exhibit high activity not only against bacteria but also against enveloped viruses such as vaccinia virus, respiratory syncytial virus, influenza A virus, HIV, herpes simplex virus, and dengue virus [15]. In goats, five cathelicidins have been described so far: Capra hirca bactenecin 3.4 (ChBAC3.4), bactenecin 5 (BAC5), bactenecin 7.5 (BAC7.5), cathelicidin 6 (MAP28), and cathelicidin 7 (MAP34). They show activity against Gram-negative and Gram-positive bacteria, as well as fungi and enveloped viruses [16-18].

As mentioned, monocytes, macrophages, and mammary epithelial cells are the target cells for SRLV. Moreover, epithelial cells of the mammary gland can act as viral reservoirs [19]. Since milk somatic cells (MSC), in addition to macrophages and neutrophils, also consist of live, exfoliated mammary epithelial cells [20], it is possible to study changes occurring not only in leukocytes but also in the SRLV-infected mammary epithelium, using a non-invasive method [21]. The aim of this study was to analyze the response of APP and cathelicidin genes to SRLV infection. Blood leukocytes (BL) and MSC were used in the present study to determine the mRNA levels of selected genes participating in the immune response to the viral infection $(S A A, H p, C R P, C p, F b \alpha, F b \beta, F b \gamma$, AGP, LALBA, ChBAC3.4, BAC5, BAC7.5, MAP28, and $M A P 34)$. In addition, ELISA was used to measure the concentrations of SAA, Hp, CRP, Cp, Fb, AGP, LALBA, MAP28, and MAP34 proteins in the blood serum and milk of uninfected and asymptomatically infected goats.

\section{Materials and methods \\ Animals}

Twenty-four dairy goats of the Polish White Improved (PWI) and Polish Fawn Improved (PFI) breeds were used in the study. They were kept in a loose barn with free access to water and a salt lick. The goats were fed according to a system developed by the Institut National de la Recherche Agronomique (INRA) of France and adopted by the National Research Institute of Animal Production (IZ PIB-INRA), Poland [22]. The basic diet consisted of maize silage, wilted grass silage, and concentrates. Goats were machine-milked twice a day. Animals were kept under the constant care of a veterinarian. For the preceding 20 years, goats from this herd had been tested serologically for SRLV twice a year (in November and June) as a part of another long-term research project.

Goats were divided into two groups: Group 1 goats were free from SRLV infection $(N=12)$ and Group 2 goats were naturally infected with SRLV $(N=12)$. Confirmation of infection was based on at least two consecutive positive serological results. Irrespectively of the serological status, all goats under study were asymptomatic. During the study, tests were also performed twice 
a year to identify new potential infections and eliminate infected animals from the control group. All serological examinations were performed using ELISA (ID Screen ${ }^{\circledR}$ MVV-CAEV, Indirect Screening ELISA, IDvet Innovative Diagnostics, Grabels, France) [23]. All goats, both healthy and infected, were held in the same environmental conditions, but separately. Goats free from SRLV were milked first to eliminate the risk of SRLV transfer via milking equipment.

Both groups were identical in terms of breed and parity. In each group, six goats of both breeds (PWI and PFI) were allocated. For each breed, there were three goats in the 2nd and three in the 4th or further lactation.

To include the changes occurring in the organisms of dairy goats in the statistical analysis, milk and blood samples were collected five times during the morning milkings during two lactations: just after kidding and on days 30 (early lactation), 60 (peak lactation), 140 (mid-lactation), and 200 (late lactation). To obtain MSC for RNA isolation, $1 \mathrm{~L}$ of milk was collected into a plastic, RNasefree bottle. Just before the milk sampling, a small amount of foremilk was also collected by hand in a sterile manner. Microbiological tests of the milk were conducted to exclude the interference of pathogenic microorganisms other than SRLV. On the same day, whole blood samples were collected by a veterinarian into S-Monovette ${ }^{\circledR} 9 \mathrm{~mL}$ EDTA tubes as well as into $9 \mathrm{~mL}$ tubes with clot-activator (Sarstedt AG \& Co., Germany). Blood was centrifuged at $3000 \mathrm{rpm}$ for $20 \mathrm{~min}$ at $4{ }^{\circ} \mathrm{C}$. The serum was harvested and frozen at $-80^{\circ} \mathrm{C}$ for further analysis.

\section{Microbiological analysis of milk}

To identify the bacterial pathogens, Columbia agar supplemented with $5 \%$ sheep blood and MacConkey agar (bioMérieux, France) were used. Both media were inoculated with $100 \mu \mathrm{L}$ of milk. Plates were incubated at $37^{\circ} \mathrm{C}$ for $48 \mathrm{~h}$. To identify the bacteria species, VITEK 2 equipment was used (bioMérieux).

\section{RNA isolation from MSC and BL}

One liter of milk was centrifuged at $1500 \mathrm{rpm}$ for $30 \mathrm{~min}$, and skimmed milk and fat phase were removed. The pellet of somatic cells was transferred to $50 \mathrm{~mL}$ Falcon $^{\text {TM }}$ Conical Centrifuge Tubes (Thermo Fisher Scientific, Poland) and washed with phosphate buffered saline (PBS); tubes were then centrifuged at $1100 \mathrm{rpm}$ for $15 \mathrm{~min}$. This operation was performed twice. The somatic cells were suspended in $1 \mathrm{~mL}$ TRIzol reagent (Invitrogen, USA) and stored at $-80^{\circ} \mathrm{C}$ for further analysis. RNA was isolated using a PureLink RNA Mini Kit (Ambion, USA) according to the manufacturer's protocol.
Total RNA from whole blood was isolated using RNA Blood Kit (Macherey-Nagel, Germany) according to the manufacturer's protocol.

Qualitative and quantitative analyses of RNA were performed using a NanoDrop 2000 spectrophotometer (NanoDrop, USA) and a 2100 BioAnalyzer (Agilent Technologies, France). Samples with RNA integrity number (RIN) values of more than seven were selected. Reverse transcription reactions were performed using the Transcriptor First Strand cDNA Synthesis Kit (Roche, Switzerland) according to the manufacturer's protocol. The cDNA samples were diluted to $50 \mathrm{ng} / \mu \mathrm{L}$ on a 386-well plate and stored at $-20^{\circ} \mathrm{C}$ for further analysis.

\section{Real-time PCR}

The expression of APP ( $S A A, H p, C R P, C p, F b \alpha, F b \beta$, Fby, AGP, LALBA) and cathelicidins (ChBAC3.4, BAC5, $B A C 7.5, M A P 28$, and MAP34) genes was measured. Real-time PCR was performed using the LightCycler 480 System (Roche, Switzerland). The sequences of primers used in the analysis and the sizes of amplification products are shown in Table 1 . To each sample, $2 \mu \mathrm{L}$ of the diluted cDNA was added, as well as $11 \mu \mathrm{L}$ of a mixture containing: $3 \mu \mathrm{L}$ of water, $6.6 \mu \mathrm{L}$ of SYBR Green Master Mix (Roche Diagnostics), $0.7 \mu \mathrm{L}$ of primer F (forward), and $0.7 \mu \mathrm{L}$ of primer $\mathrm{R}$ (reverse). For all genes, the same LightCycler 480 software program was set, with preincubation at $95{ }^{\circ} \mathrm{C}$ for $5 \mathrm{~min}$ (one cycle) and melting curve at $95{ }^{\circ} \mathrm{C}$ for $5 \mathrm{~s}$ and at $65^{\circ} \mathrm{C}$ for 1 min (one cycle). The negative control was also included. Serial twofold dilutions of template cDNA $(1,1 / 2,1 / 4,1 / 16,1 / 64)$ were also performed to determine reaction efficacy and plot calibration curve. Information on the primer annealing temperatures and cycle numbers is also shown in Table 1 . The presence of the product of interest was confirmed by electrophoresis in $2 \%$ agarose gel (visualization of product size with UV light by G-BOX device (Syngene, UK)). The cyclophilin A gene (PPIA) was used as a Ref. [24].

\section{Elisa}

APP and cathelicidins in plasma and milk were detected by ELISA and measured using a Sunrise ${ }^{\mathrm{TM}}$ microplate reader and the Magellan ${ }^{\mathrm{TM}}$ program (both from Tecan, Switzerland). Quantitation of selected proteins was carried out according to the manufacturer's protocols (SunRed, China-Cp, Fb, AGP, MAP28, MAP34; Fine Test, China-SAA, Hp, CRP, LALBA, MAP28). ELISA kits for BAC5 and BAC7.5 were not commercially available. Data were obtained on the basis of average duplicate readings for each standard, control, and sample at $450 \mathrm{~nm}$. A standard curve was generated, and a four parameter logistic curve-fit was done to calculate the results. The concentration of the tested protein is shown in $\mathrm{ng} / \mathrm{mL}$. 
Table 1 Primer sequences, position in gene, accession number in GenBank, and product sizes used in qPCR

\begin{tabular}{|c|c|c|c|c|c|c|}
\hline \multirow{2}{*}{$\begin{array}{l}\text { Gene name } \\
\text { Serum amyloid A3 protein }\end{array}$} & \multirow{2}{*}{$\begin{array}{l}\text { Gene symbol } \\
S A A\end{array}$} & \multicolumn{2}{|c|}{ Primer sequence } & \multirow{2}{*}{$\begin{array}{l}\begin{array}{l}\text { Product } \\
\text { size (bp) }\end{array} \\
69\end{array}$} & \multirow{2}{*}{$\begin{array}{l}\begin{array}{l}\text { GenBank/UniProt } \\
\text { assession }^{\mathbf{a}}\end{array} \\
\text { EU884570.1 }\end{array}$} & \multirow{2}{*}{$\begin{array}{l}\text { References } \\
{[59]}\end{array}$} \\
\hline & & $\mathrm{F}$ & CTGGGCTGCTAAAGTGATCAGTAAC & & & \\
\hline & & $\mathrm{R}$ & CCCTTGAGCAGAGGGTCTGTGATT & & & \\
\hline \multirow[t]{2}{*}{ Haptoglobin } & $H p$ & $\mathrm{~F}$ & TAATGCCCATCTGCCTAC & 162 & XM_005692202.3 & [60] \\
\hline & & $\mathrm{R}$ & CGCCCTCATAGTGTTTCA & & & \\
\hline \multirow[t]{2}{*}{ C-reactive protein } & $C R P$ & $\mathrm{~F}$ & CTGGCTTGGGAGATTG & 134 & XM_018046353.1 & [60] \\
\hline & & $\mathrm{R}$ & AGTGAGGGTAAGGGATT & & & \\
\hline \multirow[t]{2}{*}{ a-lactalbumin } & LLBA & $\mathrm{F}$ & TGACATTTGTGTGTGCCAAGA & 198 & NM_001285635.1 & PRIMER3 ${ }^{\mathrm{b}}$ \\
\hline & & $\mathrm{R}$ & CAAGGGGGTACAAAGAAGCA & & & \\
\hline \multirow[t]{2}{*}{ a-acid glycoprotein } & $A G P$ & $\mathrm{~F}$ & TTGCTTGGCTGCAGGTGT & 197 & XM_012152252.2 & [11] \\
\hline & & $\mathrm{R}$ & CAATGGTCTGGTACTCTCTCTG & & & \\
\hline \multirow[t]{2}{*}{ Ceruloplasmin } & $C p$ & $\mathrm{~F}$ & GAGCATGAAGGGGCCATTTATC & 130 & NM_001256556.1 & [61] \\
\hline & & $\mathrm{R}$ & GCTGTCTTCCTCACCAGG & & & \\
\hline \multirow[t]{2}{*}{ Fibrinogen a chain } & Fba & $\mathrm{F}$ & TGAGATCCTGAGGCGCAAAG & 104 & NM_001033626.1 & [61] \\
\hline & & $\mathrm{R}$ & TGTCCACCTCCAATCGTTTCAT & & & \\
\hline \multirow[t]{2}{*}{ Fibrinogen $\beta$ chain } & $F b \beta$ & $\mathrm{F}$ & GACAACGACGGCTGGAAAAC & 124 & NM_001142917 & [61] \\
\hline & & $\mathrm{R}$ & ACGCTCCACCCCAGTAGTAT & & & \\
\hline \multirow[t]{2}{*}{ Fibrinogen y } & $\mathrm{Fb} y$ & $\mathrm{~F}$ & TGCCAATAAGGGGGCCAAAG & 134 & NM_173911 & [61] \\
\hline & & $\mathrm{R}$ & GACTGCCATCAAGCCTCTTCT & & & \\
\hline \multirow[t]{2}{*}{ Bactenecin-5; cathelicidin-2 } & $B A C 5$ & $\mathrm{~F}$ & GTGGAATTCACGGTGAAGGAGAC & 390 & Y18873.1 & [52] \\
\hline & & $\mathrm{R}$ & CTCAGGCCAAATGAGAT & & & \\
\hline \multirow[t]{2}{*}{ Bactenecin-7.5; cathelicidin-3 } & $B A C 7.5$ & $\mathrm{~F}$ & GTGGAATTCACGGTGAAGGAGAC & 383 & AJ243125.1 & [52] \\
\hline & & $\mathrm{R}$ & AGTGCTAACCTTGATGTT & & & \\
\hline \multirow[t]{2}{*}{ Cathelicidin-6 } & MAP28 & $\mathrm{F}$ & GTGGAATTCACGGTGAAGGAGAG & 225 & AJ243126.1 & [52] \\
\hline & & $\mathrm{R}$ & AATTGGGCCGACTTTGTGCC & & & \\
\hline \multirow[t]{2}{*}{ Cathelicidin-7 } & MAP34 & $\mathrm{F}$ & ACCGAATTCAGCTACAGGGAGGCCGT & 428 & AJ243127.1 & [52] \\
\hline & & $\mathrm{R}$ & ACCTGATCCTTAGGACTTC & & & \\
\hline
\end{tabular}

bp: base pairs, F: forward primer, R: reverse primer.

a NCBI [62].

b PRIMER3 [63].

\section{Statistical analysis}

The $\mathrm{C}_{\mathrm{T}}$ values were calculated according to Pfaffl's [25] mathematical formula:

$$
\text { ratio }=\frac{\left(E_{\text {target }}\right)^{\Delta \mathrm{CP}_{\text {target }}(\text { control - sample })}}{\left(E_{\mathrm{ref}}\right)^{\Delta \mathrm{CP}}}
$$

where: ratio-expressed in a sample versus a control in comparison to a reference gene, $\Delta \mathrm{CP}_{\text {target }}-\mathrm{CP}$ deviation of control-sample of the target gene transcript, $\Delta \mathrm{CP}_{\text {ref }}$ $\mathrm{CP}$ deviation of control-sample gene reference transcript, E-real-time PCR efficiency of target (E(target)) or reference $(E(r e f))$ gene transcript.

To search for differences in gene expression levels between groups of animals and types of biological material, analyses of variance were performed using the GLM procedure with Tukey-Kramer tests (SAS/STAT), taking into account the fixed effect of the interaction of the biological material (blood or milk) and the health state of the animals (SRLV-infected or uninfected), the fixed effect of lactation stage, and error as random:

$$
y_{i j k l}=\mu+(S R L V \times T M)_{i j}+S L_{k}+e_{i j k l}
$$

where: $y_{\mathrm{ijk}}$-trait value (gene expression), $\mu$-overall mean, $(\mathrm{SRLV} \times \mathrm{TM})_{\mathrm{ij}}$-fixed effect of the interaction of the type of biological material (blood or milk) and the health state of the animals (SRLV-infected or uninfected) $\left(i^{*} \mathrm{j}=1, \ldots 4\right), \mathrm{SL}_{\mathrm{k}}$-fixed effect of $\mathrm{j}$-th stage of lactation $(\mathrm{k}=1, \ldots 5), \mathrm{e}_{\mathrm{ijk}}$-random error.

The normality of the distribution of all traits was checked using a Univariate procedure (SAS/STAT), and values for the expression of genes at the mRNA level were transformed into a natural logarithmic scale.

The final model did not contain the year of sampling, breed, lactation number, or lack/presence of bacteria because in prior preliminary analyses, these parameters were not found to impact the results. 


\section{Results}

All milk samples were free from bacterial pathogens; however, in $57 \%$ of the samples, environmental bacteria such as Staphylococcus caprae, Staphylococcus xylosus, and Staphylococcus lentus were identified (in both groups of animals and at similar levels). As mentioned above, preliminary analysis revealed that these bacteria did not influence the expression of the genes studied. Therefore, their effect was not discussed in the paper.

In this study, transcripts of $S A A, H p, C p, F b \alpha, F b y$, AGP4, LALBA, CRP, BAC5, BAC7.5, MAP28, and MAP34 genes were found in all BL and MSC samples of both SRLV-infected and uninfected goats; however, the levels of some of these differed between the groups and types of biological materials.

First, we analyzed the differences in gene expression levels between $\mathrm{BL} /$ blood serum and MSC/milk of uninfected and infected goats, separately (i.e., the gene expression levels of $\mathrm{BL} / \mathrm{blood}$ serum were compared to the expression levels of MSC/milk in uninfected goats, and the same analysis was performed for infected goats). We observed dissimilarity in the transcript levels of $C p(p<0.01)$ and Fby $(p<0.05)$ between MSC and $\mathrm{BL}$ of the uninfected goats, with higher expression of $C p$ and lower expression of $F b y$ in BL (Figure 1). At the protein level, differences were found for SAA, Hp, Cp, AGP, and CRP, with lower expression of SAA $(p \leq 0.01), \mathrm{Hp}(p \leq 0.01)$, and CRP $(p \leq 0.05)$ and higher expression of $\mathrm{Cp}(p \leq 0.01)$ and AGP $(p \leq 0.01)$ in the blood serum than in the milk of uninfected goats (Figure 2). In SRLV-infected goats, at the mRNA level, in addition to $C p(p \leq 0.01)$ and $F b \gamma(p \leq 0.01)$, expression of the MAP28 gene was also found to be higher in MSC than in BL $(p \leq 0.05)$ (Figure 3$)$. At the protein level, only SAA, Hp, and AGP had the same pattern of changes both in SRLV-infected and uninfected goats. In infected animals, there were no differences in $\mathrm{Cp}$ or CRP concentrations; however, in addition to SAA, Hp, and AGP (the same pattern as in uninfected goats), differences were found for $\mathrm{Fb}$ and MAP28 with their lower levels in blood serum than in milk $(p \leq 0.05)$ (Figure 4).

The second part of the analysis concerned the comparison of mRNA and protein levels in BL or blood serum and MSC or milk between SRLV-infected and uninfected goats. We found higher expression of $S A A$ and $H p$ genes $(p \leq 0.01)$ in BL of SRLV-infected goats (Figure 5). There were no significant differences between SRLV-infected and uninfected goats in the expression patterns of the other studied APP in BL. Moreover, in BL, no changes in the expression profile of cathelicidins were detected (Figure 5). Only elevated expression of the $\mathrm{Hp}$ gene was found $(p \leq 0.05)$ in MSC from SRLV-infected goats

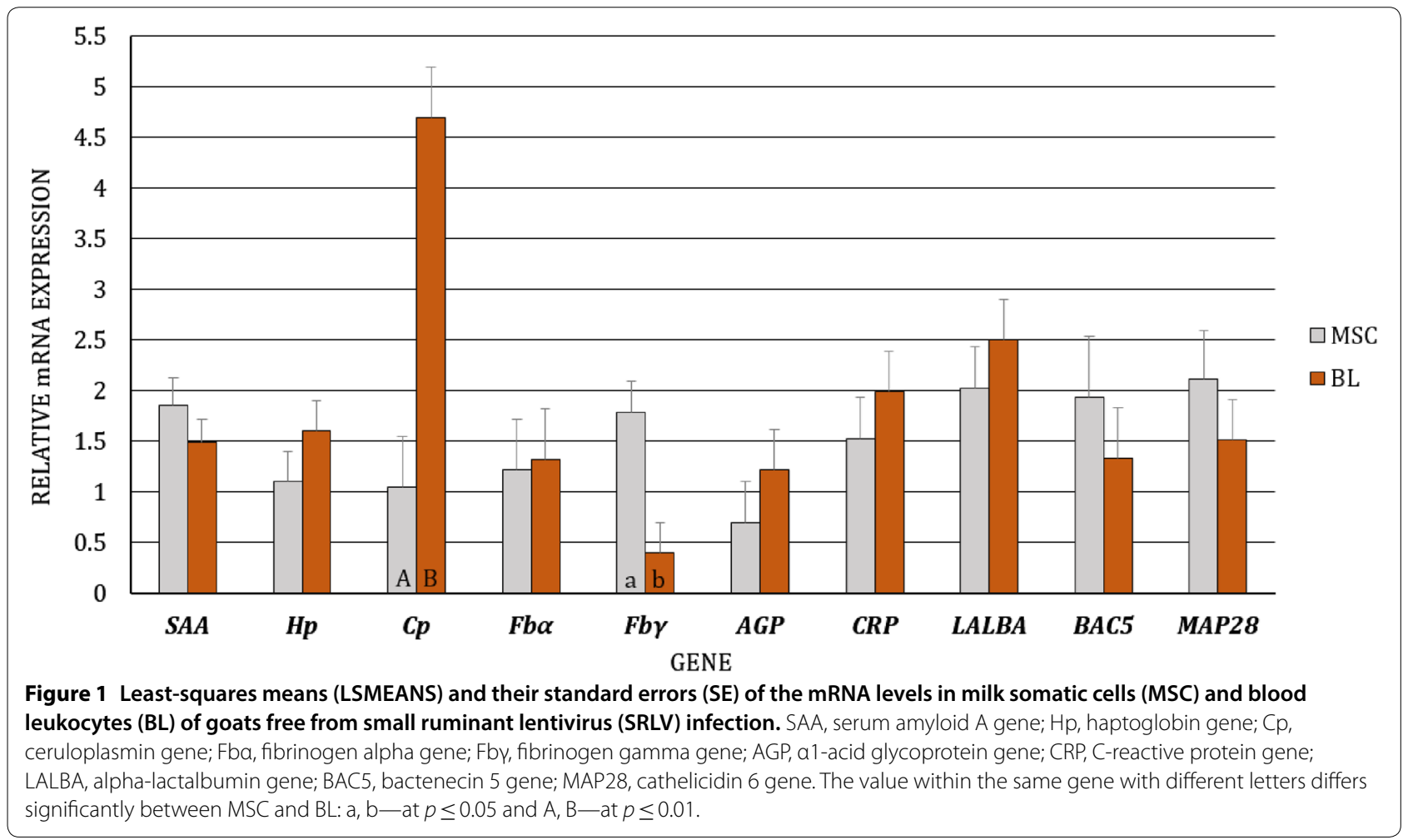




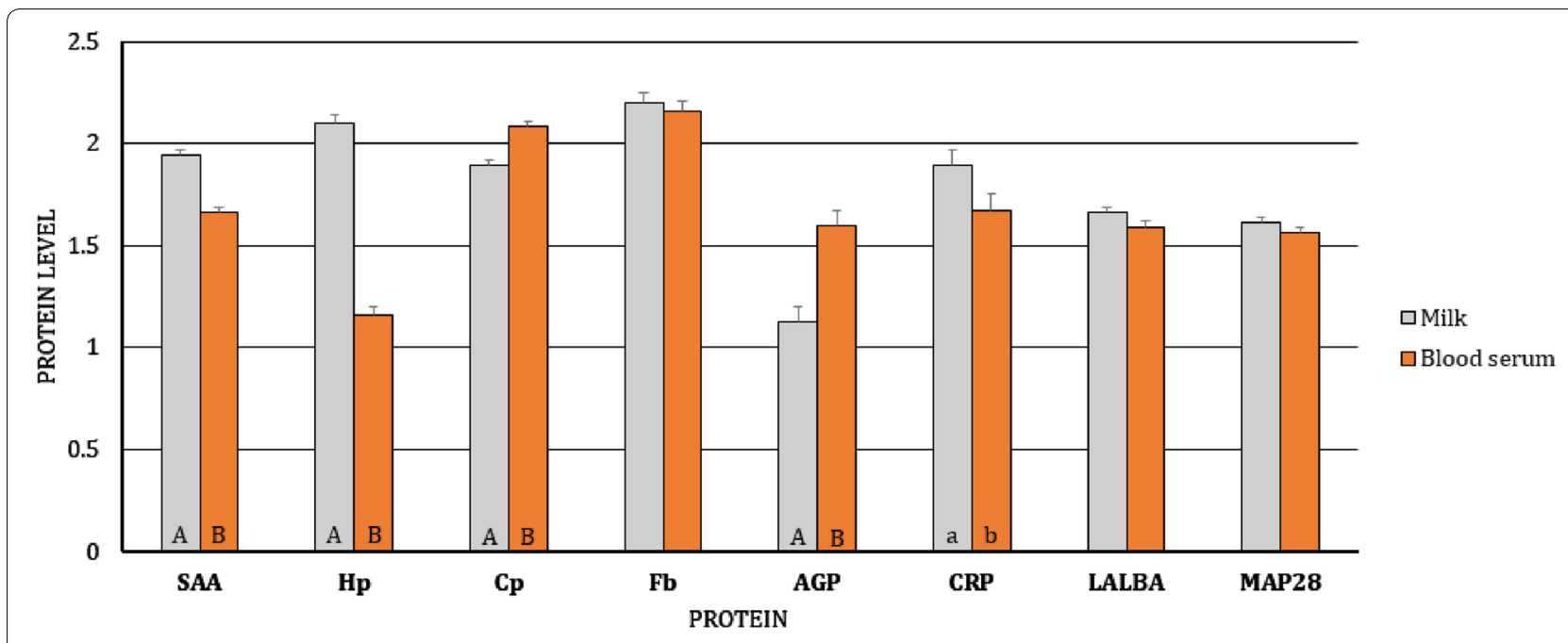

Figure 2 Least-squares means (LSMEANS) $(\mathrm{ng} / \mathrm{mL}$ ) and their standard errors (SE) of protein levels in milk and blood serum of goats free from small ruminant lentivirus (SRLV) infection. SAA, serum amyloid A; Hp, haptoglobin; Cp, ceruloplasmin; Fb, fibrinogen; AGP, a 1-acid glycoprotein; CRP, C-reactive protein; LALBA, alpha-lactalbumin; MAP28, cathelicidin 6 . The value within the same gene with different letters differs significantly between milk and blood serum: $\mathrm{a}, \mathrm{b}$ - at $p \leq 0.05$ and $\mathrm{A}, \mathrm{B}$ - at $p \leq 0.01$.

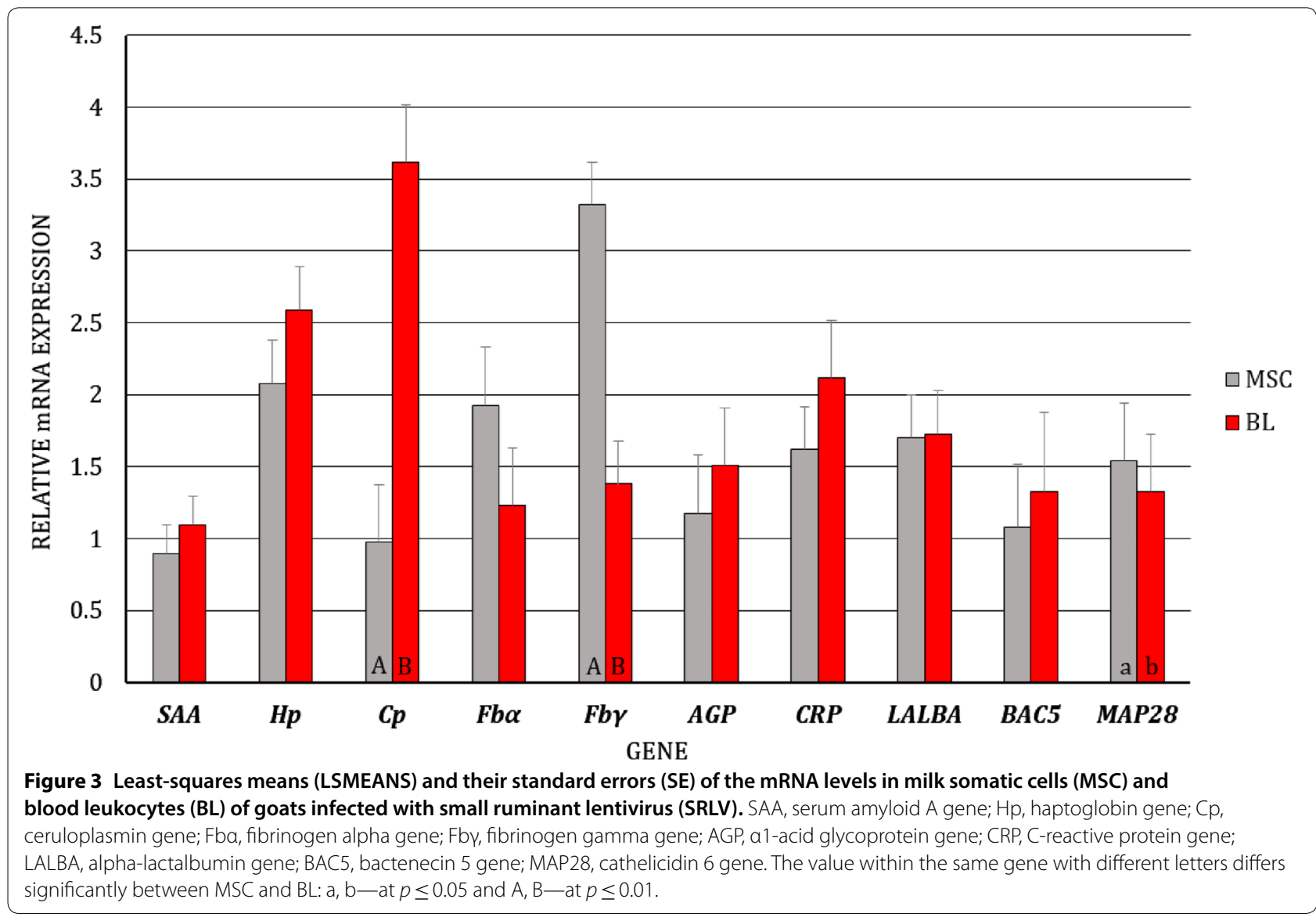



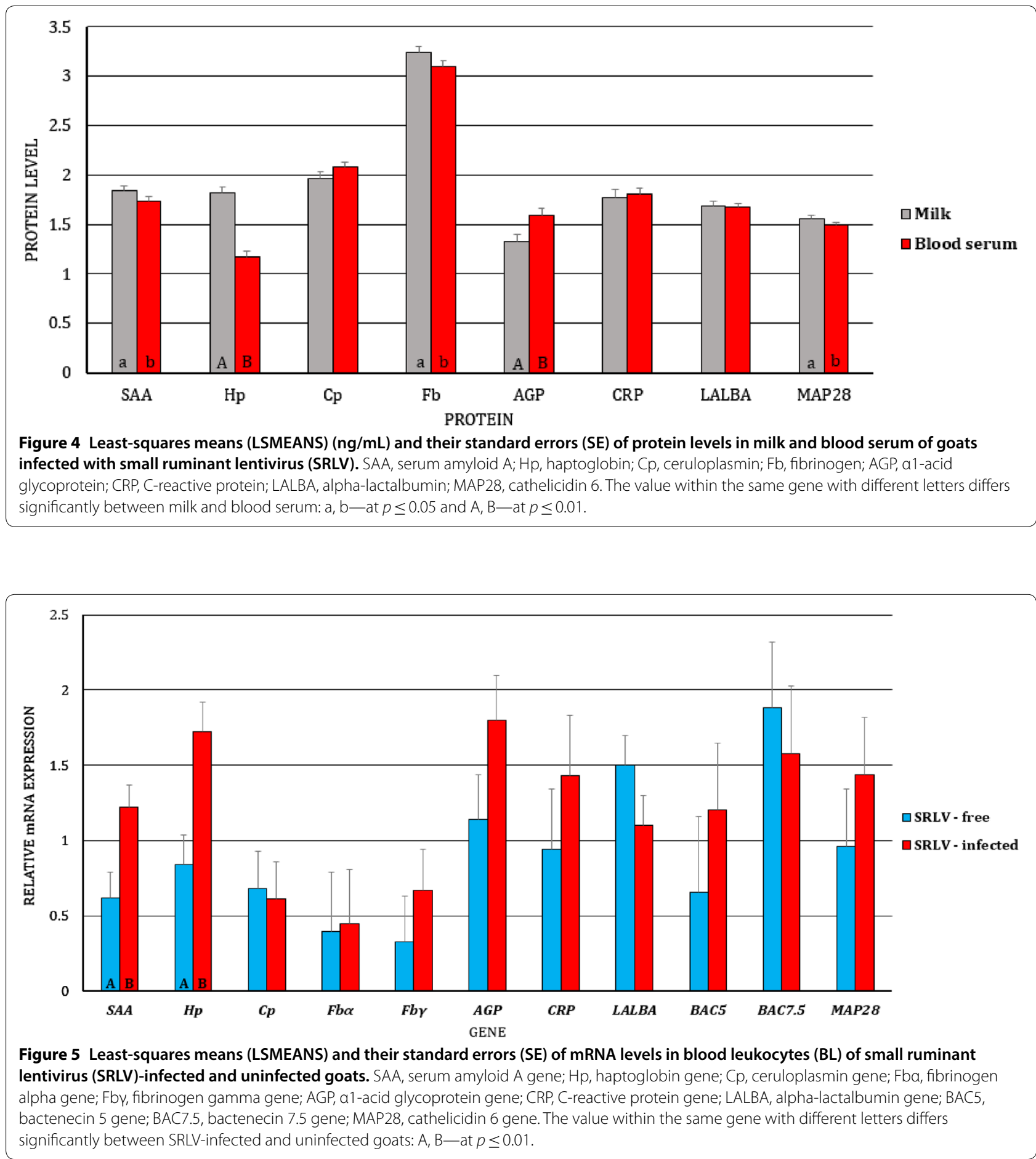

(Figure 6). No differences in $S A A$ gene expression level in MSC were observed.

Regarding the expression of the studied genes at the protein level, in BL, only a higher expression of SAA in
SRLV-infected animals was found (Figure 7), while in MSC, lower expressions of SAA, Cp, and MAP28 and a higher expression of MAP34 in infected animals was observed (Figure 8). 

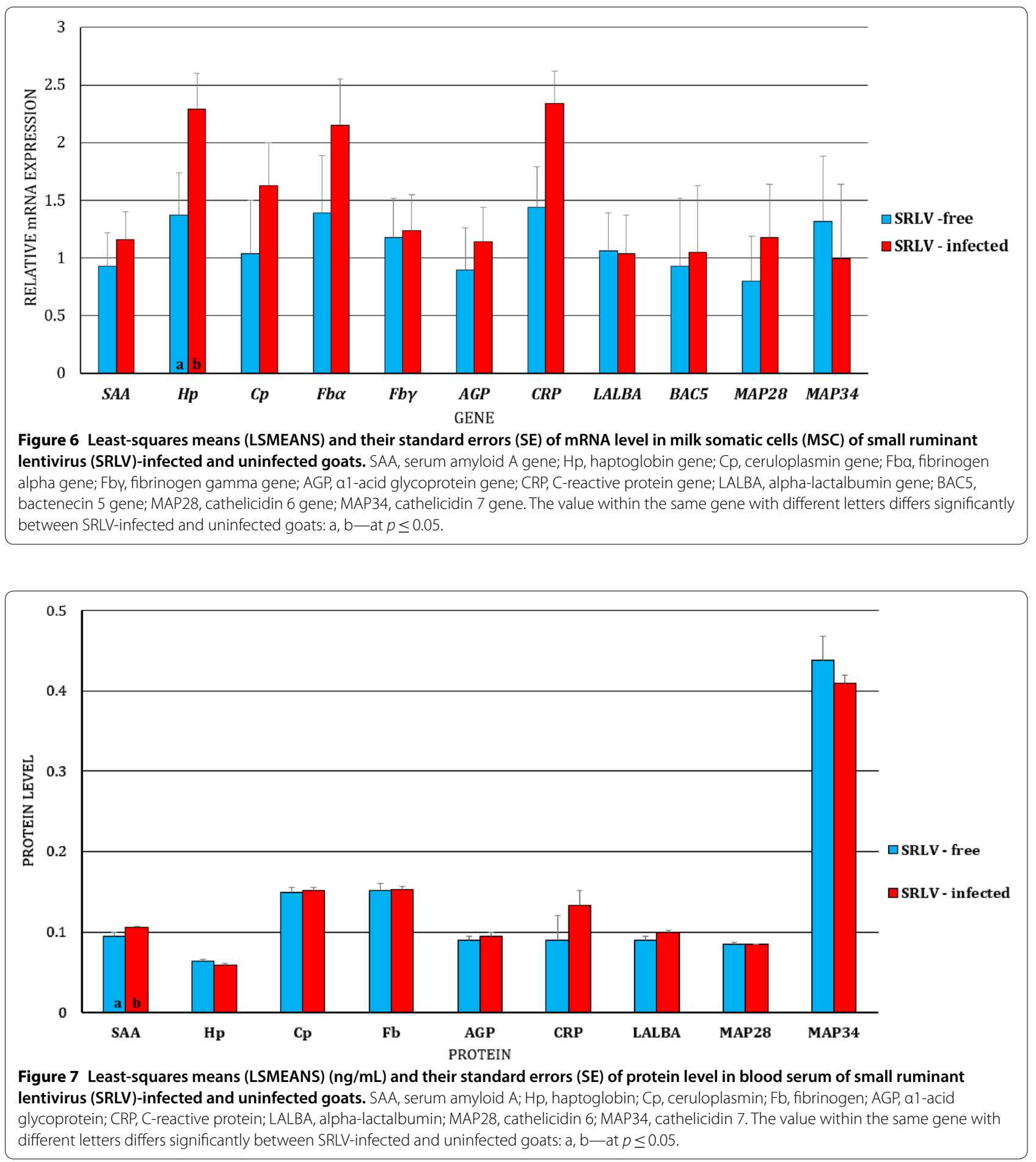

\section{Discussion}

APP are well-known elements of the immune system that react to various types of infection. Proteins from this group participate in the response to infections with different species of lentiviruses. As one of the activities of $\mathrm{Cp}$ and $\mathrm{Fb}$ is the removal of reactive oxygen species, their increased concentration may indicate their role in anti-oxidative processes in serum or milk. SAA, showing chemotactic activity toward leukocytes, plays an essential role in the pathogenesis of chronic inflammation, and it 


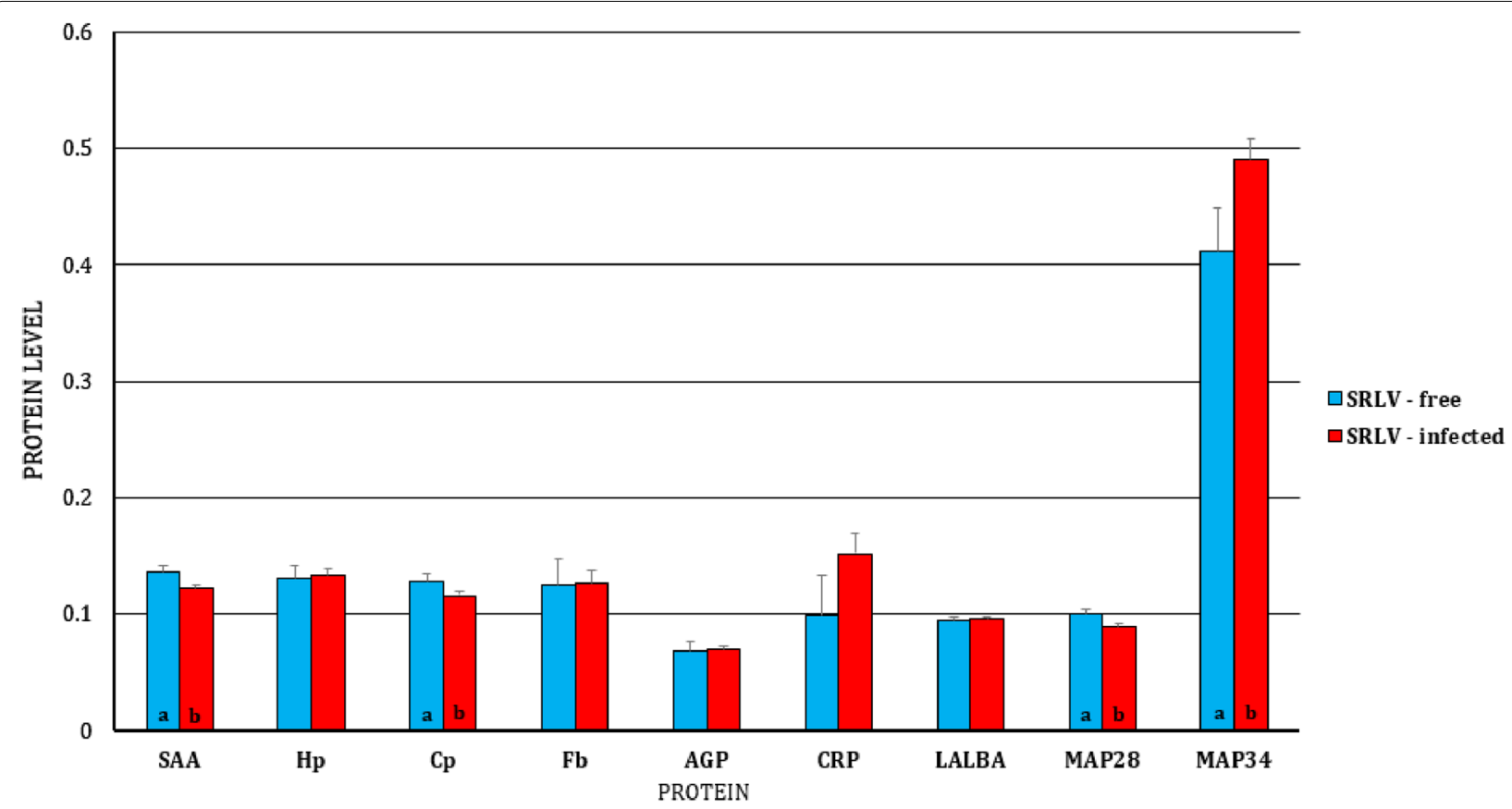

Figure 8 Least-squares means (LSMEANS) $(\mathrm{ng} / \mathrm{mL}$ ) and their standard errors (SE) of protein levels in the milk of small ruminant lentivirus (SRLV)-infected and uninfected goats. SAA, serum amyloid A; Hp, haptoglobin; Cp, ceruloplasmin; Fb, fibrinogen; AGP, a1-acid glycoprotein; CRP, C-reactive protein; LALBA, alpha-lactalbumin; MAP28, cathelicidin 6; MAP34, cathelicidin 7. The value within the same gene with different letters differs significantly between SRLV-infected and uninfected goats: $a$, $b$ - at $p \leq 0.05$.

can also serve as an early marker of inflammation. On the contrary, this APP may inhibit antibody production [26]. Moreover, SAA seems to have an ability to stimulate the differentiation of monocytes to macrophages, which is essential for viral multiplication [27]. Hp, responsible for the uptake of free hemoglobin from blood, prevents oxidative activity and therefore has an anti-oxidative and bacteriostatic effect against iron-utilizing bacteria [12, $28,29]$. Hp is produced not only by hepatocytes but also in some mammary gland tissues (e.g., the parenchyma, the tissues surrounding the cisternal milk ducts, and in the teat). Its concentration is increased both in milk and blood during inflammation of the mammary gland in dairy cows [30]. AGP was also produced in the mammary gland ductal and cisternal tissues (elevated mRNA level), as well as in alveoli (decreased mRNA level) during experimental infection with $S$. aureus in dairy cows [31]. AGP acts as an immunomodulatory and anti-inflammatory factor, and it protects tissues from excessive damage caused by the inflammation. However, in one study in cattle, it was also shown to inhibit neutrophil migration to the site of infection and thus to elevate mortality risk of the animal [28].

We found differences in the expression of $C p$ and $F b y$ genes, as well as the concentrations of SAA, Hp, and AGP proteins between MSC/milk and BL/blood serum of both infected and uninfected animals (this analysis was conducted separately for infected and uninfected animals). The expression of genes encoding APP showed a tissue-specific pattern that differed slightly between infected and uninfected animals. Thus, different APP genes may play an important role in the maintenance of homeostasis in various tissues/organs. In both groups of animals-infected and uninfected-the expression of different genes was up- or down-regulated at the mRNA and protein levels. Our findings are in accordance with the results of other authors who have shown various concentrations of APP in different tissues. Ametaj et al. [28] summarized that SAA3 was produced by adipose tissue, macrophages, and epithelial cells of the intestine and mammary gland. Molenaar et al. [32] found expression of SAA3 in the epithelial cells lining the ductal tissue of the teat, but not in alveoli, during lactation. However, many others have shown increased expression of SAA3 in cow and ewe milk during mastitis [33-35].

Changes in concentrations of APP have been observed in both infectious (bacterial and viral) [36] and noninfectious [37, 38] diseases. It has also been shown that the levels of SAA and Hp increase during lentiviral infection in cats [1,39]. Moreover, upon lipopolysaccharide (LPS) infusion, elevated levels of $\mathrm{Hp}$ and SAA in goat milk and in the blood of goats with sub-acute ruminal 
acidosis were also found [11, 38, 40]. Hp and SAA have been identified as the main APP in goats; however, after injection of turpentine oil resulting in tissue irritation and an inflammatory reaction, other APP, such as Fb, were also found to increase, while albumin decreased [14].

In the second part of the study, we found higher expressions of $S A A$ and $H p$ mRNAs in BL and an elevated concentration of SAA proteins in the blood serum of SRLV-infected goats. Although $H p$ gene mRNA was increased in MSC of SRLV-infected goats, there were no differences in $\mathrm{Hp}$ concentrations in milk. On the contrary, the concentrations of SAA and CP were lower in the milk of infected animals. However, in our previous study [7], we found higher concentrations of both SAA and $\mathrm{Hp}$ only in goats with apparent CAE, while the concentrations did not differ between asymptomatically infected and uninfected goats. We concluded from those results that the concentration of both APP may have increased in response to local joint inflammation, rather than to any general inflammatory processes caused by SRLV infection. However, there is a discrepancy between the results presented here and those obtained in our previous study [7] because here, we show a significant difference in SAA level in BL between uninfected and asymptomatic, infected goats.

The lack of difference in concentration of APP (except SAA, which probably assists in viral multiplication) in blood serum between uninfected and infected goats may mean that the virus is able to inhibit humoral immune response. Thus, the virus might be able to suppress the host defense against infection or to modify the immune response. This assumption was consistent with the results obtained by Crespo et al. [41]. Similar conclusions have also been presented by other authors, who stress that lentiviruses have the ability of immune evasion, continuing to replicate and gradually increasing their pathogenicity [42-44]. As stressed by Larusskain and Jugo [45] the SRLV could be invisible to the immune system of the host. Moreover, as suggested by Murphy [46], some lentiviruses can produce chemokine mimics that can inhibit host chemokines and help viruses infect target cells or disseminate in the host. Moreover, Pyrah and Watt [47] found that SRLV-infected sheep had a lower immune response to mycobacterial antigens, suggesting that the immunity of the host could be affected. SRLV's ability to inhibit the inflammatory reaction may be the reason that infected animals are asymptomatic for months or even years after the initial infection. Furthermore, the antibody titer fluctuates, for example, during pregnancy, and drops below the limit of detection even in animals with clinical signs of the disease [48-50].
Cathelicidins are also species-specific agents of the immune system and are especially known for their role in response to bacterial and viral infections [16]. For example, the antiviral activity of bovine BAC5 has been previously reported in the literature [15]. Elevated expression of antimicrobial peptides including cathelicidins has also been found in MSC of cows during mastitis [16, 51], while constitutive expression of $B A C 5$ and $B A C 7.5$ in MSC of uninfected goats has also been detected [24]. Moreover, Zhang et al. [52] found similar expressions of $B A C 5, B A C 7.5$, MAP28 and MAP34 genes in the mammary glands of healthy and mastitic goats. The inhibitory role of human (LL-37) and swine (protegrin-1) cathelicidins in HIV-1 infection (in vitro study) has also been reported [53, 54]. Furthermore, together with defensins, cathelicidins not only have a broad-spectrum of antimicrobial potency but also play regulatory and effector roles in the innate immune system. Some activate complement or mast cells, induce monocytes, neutrophils, $\mathrm{T}$ cells, mast, and immature dendritic cell chemotaxis, as well as cell proliferation, angiogenesis, and many others processes [55]. Information about the expression of cathelicidin genes in lentivirus infection in goats is still limited, thus it is not possible to compare our results with others. As we showed, there were no differences between the tissues of uninfected goats in cathelicidin gene expression. However, we revealed a similar pattern of expression of one cathelicidin-MAP28-at both the mRNA and protein levels, with lower expression in BL/blood serum and $\mathrm{MSC} / \mathrm{milk}$ of infected animals. Moreover, the concentration of MAP28 was reduced, while that of MAP34 was elevated, but only in the milk of SRLV-infected animals. These two cathelicidins may play vital but contradictory roles in virus infection in the milk of goats. Further study is needed to clarify these roles.

In some cases, we obtained opposite results between mRNA and protein concentrations in both BL/blood serum and MSC/milk. Thus, the discrepancy was found between gene expression at the mRNA level and protein level. In other studies, for example in a study on cytokine expression in HIV infection, increased $I L-1 \beta$ mRNA expression was found but production of the protein was lacking in astrocytes [56]. Moreover, in our earlier studies $[9,24]$, we found expression of $I F N-\gamma$ and $T N F-\alpha$ at the mRNA level in BL, with no expression of these proteins in the blood of both SRLV-infected and uninfected goats. The differences in expression patterns at the mRNA and protein levels could be explained by some post-transcriptional or post-translational modifications. To our knowledge, no other studies on this topic have been conducted in small ruminants. Thus, first of all, the microRNAs (miRNAs) responsible for regulating the maturation of APP and cathelicidin mRNAs during 
SRLV inflammation should be identified, because some of the epigenetic modifications are regulated by miRNAs through degradation or translational silencing of mRNA [57]. This could mean that lentivirus infection influences miRNA gene expression. We can only speculate whether SRLV inhibits this translational process, using mechanisms such as downregulating the expression of receptors, transcription factors, signaling enzymes, or other proteins involved in the regulation of transcription.

In summary, except for a similar study conducted on goats by Czopowicz et al. [7], it is difficult to find any comparative data for APP and cathelicidin expression profiles in small ruminants as a response to SRLV infections. Comparison of gene expression levels in lentivirus infection between species is difficult, especially since in different animal species, different proteins are classified as APP (e.g., TTR, as a negative APP, is an inflammatory marker in humans (where it is routinely measured) and swine, but in goats, TTR's role has yet to be elucidated) $[1,13,58]$. We only found an in vitro study on APP expressions in goat synovial membrane (GSM) cells isolated from the carpal synovial membrane of colostrumdeprived newborn goat kids [11]. The authors stated that AGP was constitutively produced by GSM cells. They also showed no differences in the AGP gene expression profile between healthy and SRLV-infected 2- to 4-yearold goats with clinical signs of carpal joint disease. Their results are partly in accordance with ours-we found an elevated transcript level of AGP only in MSC, not in BL.

Lower concentrations of SAA, Cp, and MAP28 in milk than in blood indicate the differences in expression profile for APP genes in various biological materials.

The elevated SAA expression in blood serum at the protein level was accompanied by decreased concentrations of SAA and Cp in the milk of infected goats. This finding may suggest that the immune response of the mammary gland differs from the humoral response. The lack of differences between infected and uninfected animals in the concentrations of other APP and cathelicidins in milk and blood may also mean that SRLV can evade the immune system. Moreover, since SAA probably inhibits the production of antibodies and inflammatory reactions, as well as stimulating the differentiation of monocytes to macrophages (which is essential for viral multiplication), elevated expression of this protein could help the virus to continuously infect new cells. The higher concentration of SAA and the unchanged concentration of other APP in the blood serum plus the simultaneous, reduced concentrations of SAA and $\mathrm{Cp}$ in the milk of SRLV-infected goats may serve as additive indicators of this infection.
The differences in expression patterns of mRNA and protein levels could be explained by post-transcriptional modifications influenced by the virus, but an epigenetic study is needed to identify these phenomena.

\begin{abstract}
Abbreviations
AGP: a1-acid glycoprotein; AMP: antimicrobial peptide; APP: acute phase protein; BAC5: bactenecin 5; BAC7.5: bactenecin 7.5; BL: blood leukocyte; CAEV: caprine arthritis encephalitis virus; Cp: ceruloplasmin; CRP: C-reactive protein; ELISA: enzyme-linked immunosorbent assay; Fb: fibrinogen; FIV: feline immunodeficiency virus; GSM: goat synovial membrane; HIV: human immunodeficiency virus; Hp: haptoglobin; IFN-ץ: interferon alpha; INRA: Institut National de la Recherche Agronomique; LALBA: alpha-lactalbumin; Lf: lactoferrin; LL-37: human cathelicidin; LSMEANS: Least-squares means; MAP28: cathelicidin 6; MAP34: cathelicidin 7; MSC: milk somatic cell; PBS: phosphate-buffered saline; PFI: Polish Fawn Improved; PPIA: cyclophilin A; PWI: Polish White Improved; SAA: serum amyloid A; SE: standard error; SIV: simian immunodeficiency virus; SRLV: small ruminant lentivirus; TNF-a: tumor necrosis factor alpha; Tf: transferrin; TTR: transthyretin; VMV: visna-maedi virus.
\end{abstract}

\section{Competing interests}

The authors declare that they have no competing interests.

\section{Authors' contributions}

DR performed data acquisition and molecular genetics studies, analyzed and interpreted the data, and drafted the manuscript. MZ performed the molecular genetics studies and drafted the manuscript. MC conceived the study and participated in its design, interpreted data, and revised the manuscript critically. JK conceived the study and participated in its design. LZ interpreted the data and revised the manuscript critically. EB conceived the study, participated in its design, performed data acquisition, analyzed and interpreted the data, and coordinated the study. All authors read and approved the final manuscript.

\section{Acknowledgements}

The authors thank Danuta Słoniewska for the assistance in laboratory analysis. Publication of the article was funded by KNOW (Leading National Research Centre) Scientific Consortium "Healthy Animal-Safe Food", decision of Ministry of Science and Higher Education No. 05-1/KNOW2/2015.

\section{Author details}

${ }^{1}$ Department of Animal Improvement, Institute of Genetics and Animal Breeding, Polish Academy of Sciences, Postępu 38A St., 05-552 Jastrzębiec, Poland. ${ }^{2}$ Laboratory of Veterinary Epidemiology and Economics, Faculty of Veterinary Medicine, Warsaw University of Life Sciences, Nowoursynowska 159c, 02-776 Warsaw, Poland. ${ }^{3}$ Department of Molecular Biology, Institute of Genetics and Animal Breeding, Polish Academy of Sciences, Postępu 38A St., 05-552 Jastrzębiec, Poland.

Ethics approval and consent to participate

The study was approved by the III Local Ethical Committee in Warsaw (Approval 31/2013)

\section{Funding}

The study was financed by the National Science Center, Poland, within the PRELUDIUM Grant, Number 2016/21/N/NZ9/01508, and OPUS Grant Number 2013/09/B/NZ6/03514.

\section{Publisher's Note}

Springer Nature remains neutral with regard to jurisdictional claims in published maps and institutional affiliations.

Received: 7 February 2018 Accepted: 24 September 2018 Published online: 13 November 2018 


\section{References}

1. Ramírez H, Reina R, Amorena B, de Andrés D, Martinez HA (2013) Small ruminant lentiviruses: genetic variability, tropism and diagnosis. Viruses 5:1175-1207

2. Minardi da Cruz JC, Singh DK, Lamara A, Chebloune Y (2013) Small ruminant lentiviruses (SRLVs) break the species barrier to acquire new host range. Viruses 5:1867-1884

3. Blacklaws BA (2012) Small ruminant lentiviruses: immunopathogenesis of visna-maedi and caprine arthritis and encephalitis virus. Comp Immunol Microbiol Infect Dis 35:259-269

4. Peluso R, Haase A, Stowring L, Edwards M, Ventura P (1985) A Trojan Horse mechanism for the spread of visna virus in monocytes. Virology 147:231-236

5. Patel JR, Heldens JGM, Bakonyi T, Rusvai M (2012) Important mammalian veterinary viral immunodiseases and their control. Vaccine 30:1767-1781

6. Peterhans E, Greenland T, Badiola J, Harkiss G, Bertoni G, Amorena B, Eliaszewicz M, Juste RA, Kraßnig R, Lafont J-P, Lenihan P, Pétursson G, Pritchard G, Thorley J, Vitu C, Mornex J-F, Pépin M (2004) Routes of transmission and consequences of small ruminant lentiviruses (SRLVs) infection and eradication schemes. Vet Res 35:257-274

7. Czopowicz M, Szaluś-Jordanow O, Mickiewicz M, Moroz A, Witkowski L, Markowska-Daniel I, StefaniakT Bagnicka E, Kaba J (2017) Haptoglobin and serum amyloid A in goats with clinical form of caprine arthritisencephalitis. Small Rumin Res 156:73-77

8. Herrmann-Hoesing LM, Broughton-Neiswanger LE, Gouine KC, White SN, Mousel MR, Lewis GS, Marshall KL, Knowles DP (2010) Evaluation of a caprine arthritis-encephalitis virus/maedi-visna virus indirect enzyme-linked immunosorbent assay in the serological diagnosis of ovine progressive pneumonia virus in U.S. sheep. Clin Vaccine Immunol 17:307-310

9. Jarczak J, Kaba J, Reczyńska D, Bagnicka E (2016) Impaired expression of cytokines as a result of viral infections with an emphasis on small ruminant lentivirus infection in goats. Viruses 8:186

10. Crespo H, Bertolotti L, Proffiti M, Cascio P, Cerruti F, Acutis PL, de Andrés D, Reina R, Rosati S (2016) Low proviral small ruminant lentivirus load as biomarker of natural restriction in goats. Vet Microbiol 192:152-162

11. Ceciliani F, Ceron JJ, Eckersall PD, Sauerwein H (2012) Acute phase proteins in ruminants. J Proteomics 75:4207-4231

12. Jain S, Gautam V, Naseem S (2011) Acute-phase proteins: as diagnostic tool. J Pharm Bioallied Sci 3:118

13. Tothova C, Nagy O, Kovac G (2014) Acute phase proteins and their use in the diagnosis of diseases in ruminants: a review. Vet Med (Praha) 59:163-180

14. González FH, Tecles F, Martínez-Subiela S, Tvarijonaviciute A, Soler L, Cerón JJ (2008) Acute phase protein response in goats. J Vet Diagn Invest 20:580-584

15. Barlow PG, Findlay EG, Currie SM, Davidson DJ (2014) Antiviral potential of cathelicidins. Future Microbiol 9:55-73

16. Kościuczuk EM, Lisowski P, Jarczak J, Strzałkowska N, Jóźwik A Horbańczuk J, Krzyżewski J, Zwierzchowski L, Bagnicka E (2012) Cathelicidins: family of antimicrobial peptides. A review. Mol Biol Rep 39:10957-10970

17. Shamova O, Orlov D, Stegemann C, Czihal P, Hoffmann R, Brogden K, Kolodkin N, Sakuta G, Tossi A, Sahl H-G, Kokryakov V, Lehrer R (2009) ChBac3.4: a novel proline-rich antimicrobial peptide from goat leukocytes. Int J Pept Res Ther 15:31-42

18. Travis SM, Anderson NN, Forsyth WR, Espiritu C, Conway BD, Greenberg EP, McCray PB, Lehrer RI, Welsh MJ, Tack BF (2000) Bactericidal activity of mammalian cathelicidin-derived peptides. Infect Immun 68:2748-2755

19. Lerondelle C, Godet M, Mornex J-F (1999) Infection of primary cultures of mammary epithelial cells by small ruminant lentiviruses. Vet Res 30:467-474

20. Bagnicka E, Winnicka A, Jóźwik A, Rzewuska M, Strzałkowska N, Kościuczuk E, Prusak B, Kaba J, Horbańczuk J, Krzyżewski J (2011) Relationship between somatic cell count and bacterial pathogens in goat milk. Small Rumin Res 100:72-77

21. Boutinaud M, Herve L, Lollivier V (2015) Mammary epithelial cells isolated from milk are a valuable, non-invasive source of mammary transcripts. Front Genet 6:323
22. IZ PIB-INRA (2009) IZ PIB-INRA: Standard of ruminants' feeding: nutrient value of French and domestic fodders for ruminants) Strzelecki (Ed.). Research Institute of Animal Production, Cracow, Poland (in Polish)

23. Czopowicz M, Szaluś-Jordanow O, Moroz A, Mickiewicz M, Witkowski L, Markowska-Daniel I, Bagnicka E, Kaba J (2018) Use of two commercial caprine arthritis-encephalitis immunoenzymatic assays for screening of arthritic goats. J Vet Diagn Invest 30:36-41

24. Jarczak J, Kaba J, Bagnicka E (2014) The validation of housekeeping genes as a reference in quantitative Real Time PCR analysis: application in the milk somatic cells and frozen whole blood of goats infected with caprine arthritis encephalitis virus. Gene 549:280-285

25. Pfaffl MW (2001) A new mathematical model for relative quantification in real-time RT-PCR. Nucleic Acids Res 29:e45

26. Jensen LE, Whitehead AS (1998) Regulation of serum amyloid A protein expression during the acute-phase response. Biochem J 334:489-503

27. Badolato R, Wang JM, Murphy WJ, Lloyd AR, Michiel DF, Bausserman LL, Kelvin DJ, Oppenheim JJ (1994) Serum amyloid A is a chemoattractant: induction of migration, adhesion, and tissue infiltration of monocytes and polymorphonuclear leukocytes. J Exp Med 180:203-209

28. Ametaj BN, Hosseini A, Odhiambo JF, lqbal S, Sharma S, Deng Q, Lam TH, Farooq U, Zebeli Q, Dunn SM (2011) Application of acute phase proteins for monitoring inflammatory states in cattle. In: Veas F (ed) Acute phase proteins as early non-specific biomarkers of human and veterinary diseases. InTech, Rijeka

29. El-Deeb WM, Tharwat M (2015) Lipoproteins profile, acute phase proteins, proinflammatory cytokines and oxidative stress biomarkers in sheep with pneumonic pasteurellosis. Comp Clin Pathol 24:581-588

30. Hiss S, Mielenz M, Bruckmaier RM, Sauerwein H (2004) Haptoglobin concentrations in blood and milk after endotoxin challenge and quantification of mammary Hp mRNA expression. J Dairy Sci 87:3778-3784

31. Whelehan CJ, Meade KG, Eckersall PD, Young FJ, O'Farrelly C (2011) Experimental Staphylococcus aureus infection of the mammary gland induces region-specific changes in innate immune gene expression. Vet Immunol Immunopathol 140:181-189

32. Molenaar AJ, Harris DP, Rajan GH, Pearson ML, Callaghan MR, Sommer L, Farr VC, Oden KE, Miles MC, Petrov RS, Good LL, Singh K, McLaren RD, Prosser CG, Kim KS, Wieliczko RJ, Dines MH, Johannessen KM, Grigor MR, Davis SR, Stelwagen K (2009) The acute-phase protein serum amyloid $\mathrm{A} 3$ is expressed in the bovine mammary gland and plays a role in host defence. Biomarkers 14:26-37

33. Eckersall PD, Young FJ, Nolan AM, Knight CH, McComb C, Waterston MM, Hogarth CJ, Scott EM, Fitzpatrick JL (2006) Acute phase proteins in bovine milk in an experimental model of Staphylococcus aureus subclinical mastitis. J Dairy Sci 89:1488-1501

34. Larson MA, Weber A, McDonald TL (2006) Bovine serum amyloid A3 gene structure and promoter analysis: induced transcriptional expression by bacterial components and the hormone prolactin. Gene 380:104-110

35. Nielsen BH, Jacobsen S, Andersen PH, Niewold TA, Heegaard PMH (2004) Acute phase protein concentrations in serum and milk from healthy cows, cows with clinical mastitis and cows with extra mammary inflammatory conditions. Vet Rec 154:361-365

36. Heller MC, Johns JL (2015) Acute phase proteins in healthy goats: establishment of reference intervals. J Vet Diagn Invest 27:177-181

37. Jia YY, Wang SQ, Ni YD, Zhang YS, Zhuang S, Shen XZ (2014) High concentrate-induced subacute ruminal acidosis (SARA) increases plasma acute phase proteins (APPs) and cortisol in goats. Anim Int J Anim Biosci 8:1433-1438

38. Olumee-Shabon Z, Swain T, Smith EA, Tall E, Boehmer JL (2013) Proteomic analysis of differentially expressed proteins in caprine milk during experimentally induced endotoxin mastitis. J Dairy Sci 96:2903-2912

39. Minguijón E, Reina R, Pérez M, Polledo L, Villoria M, Ramirez H, Leginagoikoa I, Badiola JJ, Garcia-Marin JF, de Andrés D, Lujan L, Amorena B, Juste RA (2015) Small ruminant lentivirus infections and diseases. Vet Microbiol 181:75-89

40. Stonos N, Wootton SK, Karrow N (2014) Immunogenetics of small ruminant lentiviral infections. Viruses 6:3311-3333

41. Crespo H, Bertolotti L, Jaganaru M, Glaria I, de Andrés D, Amorena B, Rosati S, Reina R (2013) Small ruminant macrophage polarization may play a pivotal role on lentiviral infection. Vet Res 44:83 
42. Blacklaws BA, Bird P, Allen D (1995) Initial lentivirus-host interactions within lymph nodes: a study of maedi-visna virus infection in sheep. J Virol 69(3):1400-1407

43. Perry LL, Wilkerson JJ, Hullinger GA, Cheevers WP (1995) Depressed CD4+T lymphocyte proliferative response and enhanced antibody response to viral antigen in chronic lentivirus-induced arthritis. J Infect Dis 171:328-334

44. Reina R, Glaria I, Benavides J (2007) Association of CD80 and CD86 expression levels with disease status of Visna/Maedi virus infected sheep. Viral Immunol 20:609-622

45. Larruskain A, Jugo BM (2013) Retroviral infections in sheep and goats: small ruminant lentiviruses and host interaction. Viruses 5:2043-2061

46. Murphy PM (2001) Viral exploitation and subversion of the immune system through chemokine mimicry. Nat Immunol 2:116-122

47. Pyrah IT, Watt NJ (1996) Immunohistological study of the depressed cutaneous DTH response in sheep naturally infected with an ovine lentivirus (Maedi-Visna virus). Clin Exp Immunol 104:32-36

48. de Andrés D, Klein D, Watt NJ, Berriatua E, Torsteinsdottir S, Blacklaws BA, Harkiss GD (2005) Diagnostic tests for small ruminant lentiviruses. Vet Microbiol 107:49-62

49. Czopowicz Szaluś-Jordanow, Mickiewicz Witkowski L, Markowska-Daniel I, Stefaniak T, Reczyńska D, Bagnicka E, Kaba J (2017) Acute-phase proteins in pregnant goats: a longitudinal study. J Vet Diagn Invest 29:814-819

50. Houwers DJ, Gielkens AL, Schaake J (1982) An indirect enzyme-linked immunosorbent assay (ELISA) for the detection of antibodies to maedivisna virus. Vet Microbiol 7:209-219

51. Kościuczuk EM, Lisowski P, Jarczak J, Krzyżewski J, Zwierzchowski L, Bagnicka $E$ (2014) Expression patterns of $\beta$-defensin and cathelicidin genes in parenchyma of bovine mammary gland infected with coagulase-positive or coagulase-negative Staphylococci. BMC Vet Res 10:246

52. Zhang G-W, Lai S-J, Yoshimura Y, Isobe N (2014) Expression of cathelicidins mRNA in the goat mammary gland and effect of the intramammary infusion of lipopolysaccharide on milk cathelicidin-2 concentration. Vet Microbiol 170:125-134
53. Steinstraesser L, Tippler B, Mertens J, Lamme E, Homann HH, Lenhardt M, Wildner O, Steinau HU, Uberla K (2005) Inhibition of early steps in the lentiviral replication cycle by cathelicidin host defense peptides. Retrovirology 2:2

54. Wong JH, Legowska A, Rolka K, Ng TB, Hui M, Cho CH, Lam WW, Au SW, Gu OW, Wan DC (2011) Effects of cathelicidin and its fragments on three key enzymes of HIV-1. Peptides 32:1117-1122

55. Berczi l, Bertók L, Chow DA (2005) Host defence: an interaction of neuroendocrine-, metabolic- and immune mechanisms in the interest of survival. Neurolmmune Biol 5:3-25

56. Nath A, Conant K, Chen P, Scott C, Major EO (1999) Transient exposure to HIV-1 Tat protein results in cytokine production in macrophages and astrocytes. A hit and run phenomenon. J Biol Chem 274:17098-17102

57. Pasquinelli AE (2012) MicroRNAs and their targets: recognition, regulation and an emerging reciprocal relationship. Nat Rev Genet 13:271-282

58. Iliev PT, Georgieva TM (2016) Acute phase proteins in sheep and goatsfunction, reference ranges and assessment methods: an overview. Bulg J Vet Med 1:1311-1477

59. Brenaut $P$, Lefèvre L, Rau A, Laloë D, Pisoni G, Moroni P, Bevilacqua C, Martin P (2014) Contribution of mammary epithelial cells to the immune response during early stages of a bacterial infection to Staphylococcus aureus. Vet Res 45:16

60. Dong H, Wang S, Jia Y, Ni Y, Zhang Y, Zhuang S, Shen X, Zhao R (2013) Long-term effects of subacute ruminal acidosis (SARA) on milk quality and hepatic gene expression in lactating goats fed a high-concentrate diet. PLoS One 8:e82850

61. Restelli L, Codrea MC, Savoini G, Ceciliani F, Bendixen E (2014) LC-MS/MS analysis of visceral and subcutaneous adipose tissue proteomes in young goats with focus on innate immunity and inflammation related proteins. J Proteomics 108:295-305

62. NCBI http://www.ncbi.nlm.nih.gov

63. PRIMER3 http://bioinfo.ut.ee/primer3-0.4.0
Ready to submit your research? Choose BMC and benefit from:

- fast, convenient online submission

- thorough peer review by experienced researchers in your field

- rapid publication on acceptance

- support for research data, including large and complex data types

- gold Open Access which fosters wider collaboration and increased citations

- maximum visibility for your research: over 100M website views per year

At BMC, research is always in progress.

Learn more biomedcentral.com/submissions 